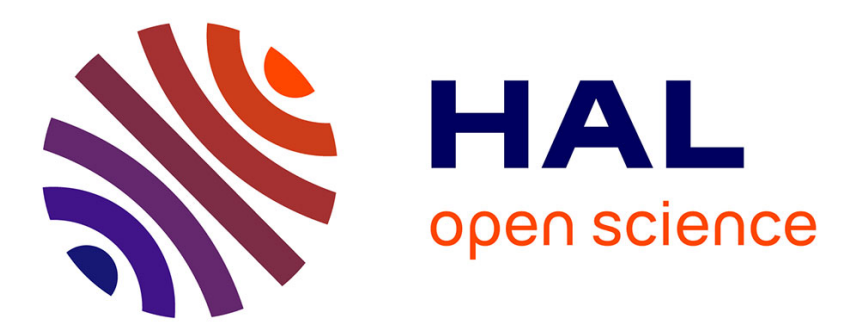

\title{
Detection of landfill cover damage using geophysical methods
}

Fanny Genelle, Colette Sirieix, Joëlle Riss, Véronique Naudet, Stéphane Renie, Michel Dabas, Philippe Begassat, Fabien Naessens

\section{To cite this version:}

Fanny Genelle, Colette Sirieix, Joëlle Riss, Véronique Naudet, Stéphane Renie, et al.. Detection of landfill cover damage using geophysical methods. Near Surface Geophysics, 2014, 12 (5), pp.599-611. 10.3997/1873-0604.2014018. halshs-01513123

\section{HAL Id: halshs-01513123 \\ https://shs.hal.science/halshs-01513123}

Submitted on 24 Apr 2017

HAL is a multi-disciplinary open access archive for the deposit and dissemination of scientific research documents, whether they are published or not. The documents may come from teaching and research institutions in France or abroad, or from public or private research centers.
L'archive ouverte pluridisciplinaire HAL, est destinée au dépôt et à la diffusion de documents scientifiques de niveau recherche, publiés ou non, émanant des établissements d'enseignement et de recherche français ou étrangers, des laboratoires publics ou privés. 


\section{DETECTION OF LANDFILL COVER DAMAGES WITH GEOPHYSICAL METHODS}

Fanny GENELLE ${ }^{1,2}$, Colette SIRIEIX ${ }^{1}$, Joëlle RISS ${ }^{1}$, Véronique NAUDET ${ }^{1,3}$, Stéphane RENIE $^{2}$, Michel DABAS ${ }^{4}$, Philippe BEGASSAT ${ }^{5}$, Fabien NAESSENS ${ }^{1}$

${ }^{1}$ Univ. Bordeaux, I2M, UMR 5295, F-33400 Talence, France ;

${ }^{2}$ HYDRO INVEST, 514 route d'Agris, 16430 Champniers, France;

${ }^{3}$ BRGM, 3 avenue Claude Guillemin, 45060 Orléans, France;

${ }^{4}$ GEOCARTA, 5 rue de la banque, 75002 Paris, France ;

${ }^{5}$ ADEME, 20 avenue du Grésillé, BP 90406, 49004 Angers cedex 1, France ;

\section{Abstract}

On closed landfills, impermeable covers are capping the waste in order to minimize water infiltration and accumulation of leachate inside the waste. In France, the cover composition depends notably on the kind of stored waste. In cases of hazardous waste, the cover must be composed of a drainage layer under the top soil and a geomembrane or a Geosynthetic Clay Liner (GCL) associated with an underlying $1.0 \mathrm{~m}$ thick low permeability material to ensure its tightness. However, this protection cover is sometimes damaged leading to an escape of landfill gazes and an unusual increase of leachate within the waste after rainy events. As leachate treatment is very expensive, it appears necessary to locate the weakness zones of the cover and assess their sizes in order to limit maintenance cost on landfills. In order to detect damages in the cover, the 
following geophysical methods have been carried out on a French landfill: cartography with an Automatic Resistivity Profiling (ARPC), the Electrical Resistivity Tomography (ERT) and the Self Potential method (SP). The joint use of these methods has given us the opportunity to determine the contribution of each of them for cover's characterization. The ARP survey has put in evidence the lateral heterogeneity of cover materials on the whole landfill. The ERT has confirmed the variability of the cover composition but also provided information about the cover thickness and the damaging

of the GCL. SP measurements have revealed a negative anomaly at the top of the landfill, possibly linked with a thin and damaged cover and therefore a greater proximity of waste. Finally, manual augers holes have enabled to associate electrical resistivity properties with different materials used in the cover and the damaged GCL. This study on a hazardous waste landfill shows that geophysical methods associated with manual auger holes have allowed to improve the knowledge of the cover. Thus, the damaged areas detected thanks to measurements performed on site may be useful for the landfill manager who can optimize the drilling survey necessary to check the nature of defects and then choose a suited remediation of the cover.

\section{Introduction}

Landfills are consisted of several cells filled with waste that are separated from the underlying soil by a passive security barrier (low permeability clay) associated with an active barrier (for example a geomembrane). At the end of the waste storage, cells are protected with a cover so as to minimize infiltration of water into the waste and therefore reduce the quantity of leachate. In cases of hazardous waste landfills, the 
cover must contain a geomembrane or a Geosynthetic Clay Liner (GCL) which notably takes part in the cover impermeability (law of December $18^{\text {th }} 1992$ published in the French journal officiel on March $30^{\text {th }}$ 1993). Although ideal barriers would never be damaged, real covers are often cracked and eroded due to mechanical, climatic and hydraulic stresses acting on their surface (ageing processes), or even be damaged during their laying. As leachate treatment is very expensive and proportional to its quantity, tightness properties of covers must be ensured over time to limit maintenance cost on landfills. Thus, locating damaged areas is crucial to limit leachate increase within the landfill, that's why covers monitoring is a topical subject.

Just after geomembrane installation at the bottom of cells, several electrical methods have proved their efficiency for checking the geomembrane integrity (Forget et al. 2005; ASTM D6747). One of these methods consists in applying an electrical current between one electrode placed above the geomembrane and a second one at a remote location outside the cells, and then measuring electrical potentials thanks to a permanent grid of electrodes placed beneath the liner (White and Barker 1997). These potential measurements can also be performed using the Electrical Leak Imaging Method (ELIM) thanks to a couple of electrodes moving above the geomembrane, either in the waste material (Colucci et al. 1999) or in the drainage layer (Laine et al. 1997). Since most synthetic geomembranes are effective electrical insulators, the presence of a leak creates a localized passage of current, which perturbs the potential field in a characteristic way. Moreover, the ELIM method can be applied when the geomembrane takes part in the landfill cap system (Hansen and Beck 2009; Beck 2011). However, the detection of defects in this latter case is only possible in particular conditions depending on the nature of the soil and its thickness. All these methods are 
mainly efficient before waste storage but not in old closed landfills as some electrodes must be placed in the waste or beneath the liner. Therefore in cases of old landfills, checking the integrity of covers in a cost and effective way requires to find non invasive techniques. Thus, the anomalous areas detected by these methods, and possibly linked with cover damages, would then be checked by a drilling survey performed on these locations.

As they are non-destructive, geophysical methods can be very interesting tool for detecting damages in covers. Up to now, these methods have mainly been used to characterize contaminated plumes (Ogilvy et al. 2002; Naudet et al. 2004; Chambers et al. 2010; Gallas et al. 2010), or to precise the nature of materials and waste in place (Guérin et al. 2004; Leroux et al. 2007; Boudreault et al. 2010; Vaudelet et al. 2011). As leachate is electrically very conductive, it is a suitable target for the electrical methods especially to monitor leachate recirculation in bioreactor (Grellier et al. 2008; Clément et al. 2011). To our knowledge, little attention and few published studies have used geophysical methods to characterize cover on landfills (Carpenter et al. 1991; Cassiani et al. 2008). Other works have been undertaken on experimental sites in more controlled conditions to test the feasibility of geophysical methods in the detection of cover heterogeneities (Guyonnet et al. 2003; Genelle et al. 2011a).

In this study, we attempt to test three geophysical methods on an old hazardous waste French landfill : the Automatic Resistivity Profiling (ARPC), the Self Potential (SP) and the Electrical Resistivity Tomography (ERT). These methods have been previously carried out on an experimental site, which reproduces two kinds of covers containing heterogeneities incorporated in a controlled fashion (Genelle et al. 2010; Genelle et al. 2011b). They have been chosen as they are sensitive to several parameters 
such as lithology (clay content), water content, water flow, and compaction. As the ARPC system is tracked by a quad, its data acquisition is rapid and therefore interesting to scan the overall surface of the landfill in a time effective way. Then, the SP and ERT methods can be used on selected anomalous zones detected by ARP. By combining these methods, the knowledge of the cover should be improved by locating its possible damages and assessing their size. Geophysical results should help the site managers to carry out the necessary drilling survey with the aim of controlling damages, and then to optimize a suited remediation of the cover (total rebuilding or just on a specific area).

\section{Site description and methods}

\subsection{The landfill}

The studied site is an old French hazardous waste landfill settled on a former clay quarry of lower Permian age. During the exploitation of the landfill, around 400 000 tons of hazardous waste were stored from 1978 to 1988 on a 42000 square meters area. Twelve cells were filled by alternate layers of a one meter-thick waste (previously mixed with clay) and a 0.3 meter-thick clay, leading to a waste dome of around $13 \mathrm{~m}$ height. In 1992, all the cells have been leveled and reshaped to the extent that they were no more distinguishable from one to each other. After this remodeling phase, an impermeable barrier covers the entire waste in order to limit vertical water seepage. Figure 1 presents the theoretical log of the $2.3 \mathrm{~m}$ thick cover composed of an alternation of clayey sand and clay layers. The $7 \mathrm{~mm}$ thick Geosynthetic Clay Liner (GCL) is placed at around $1.1 \mathrm{~m}$ deep. A vertical cement-bentonite cutoff wall encloses the landfill to prevent water entry inside the landfill (Fig. 2). Despite this cover and the 
wall, the amount of leachate inside the landfill is considered abnormally high after all rainy events, suggesting water infiltration.

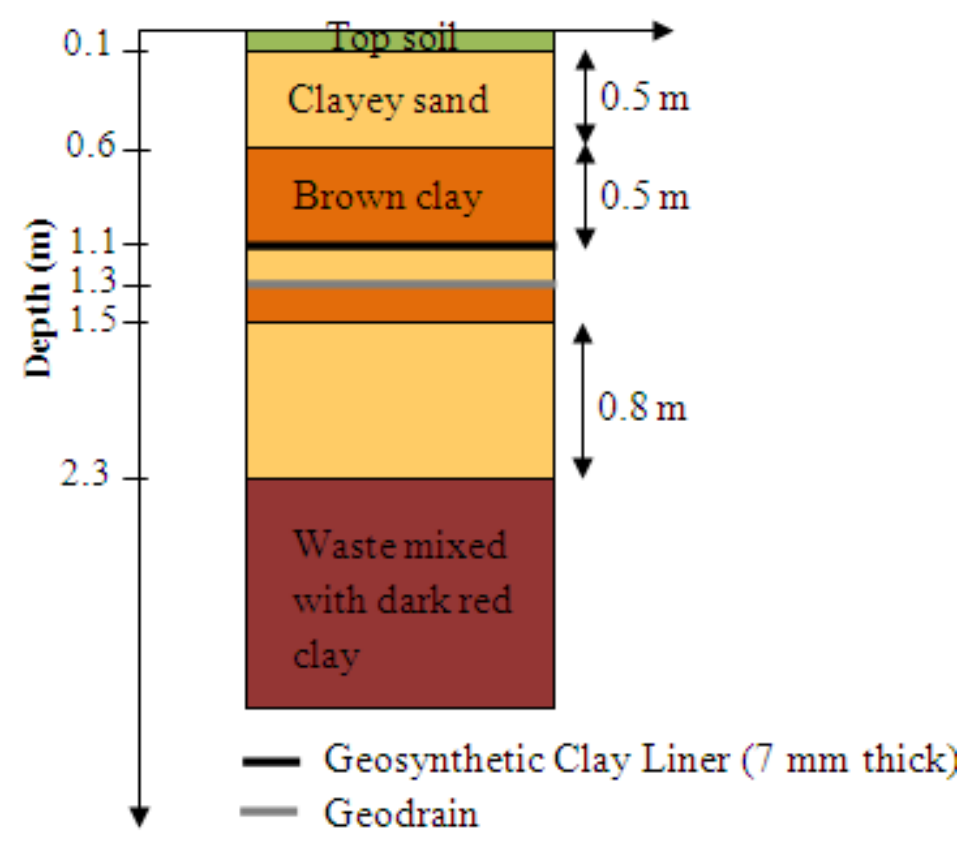

Figure 1 The theoretical cover composition installed in 1992 on the French hazardous waste landfill.

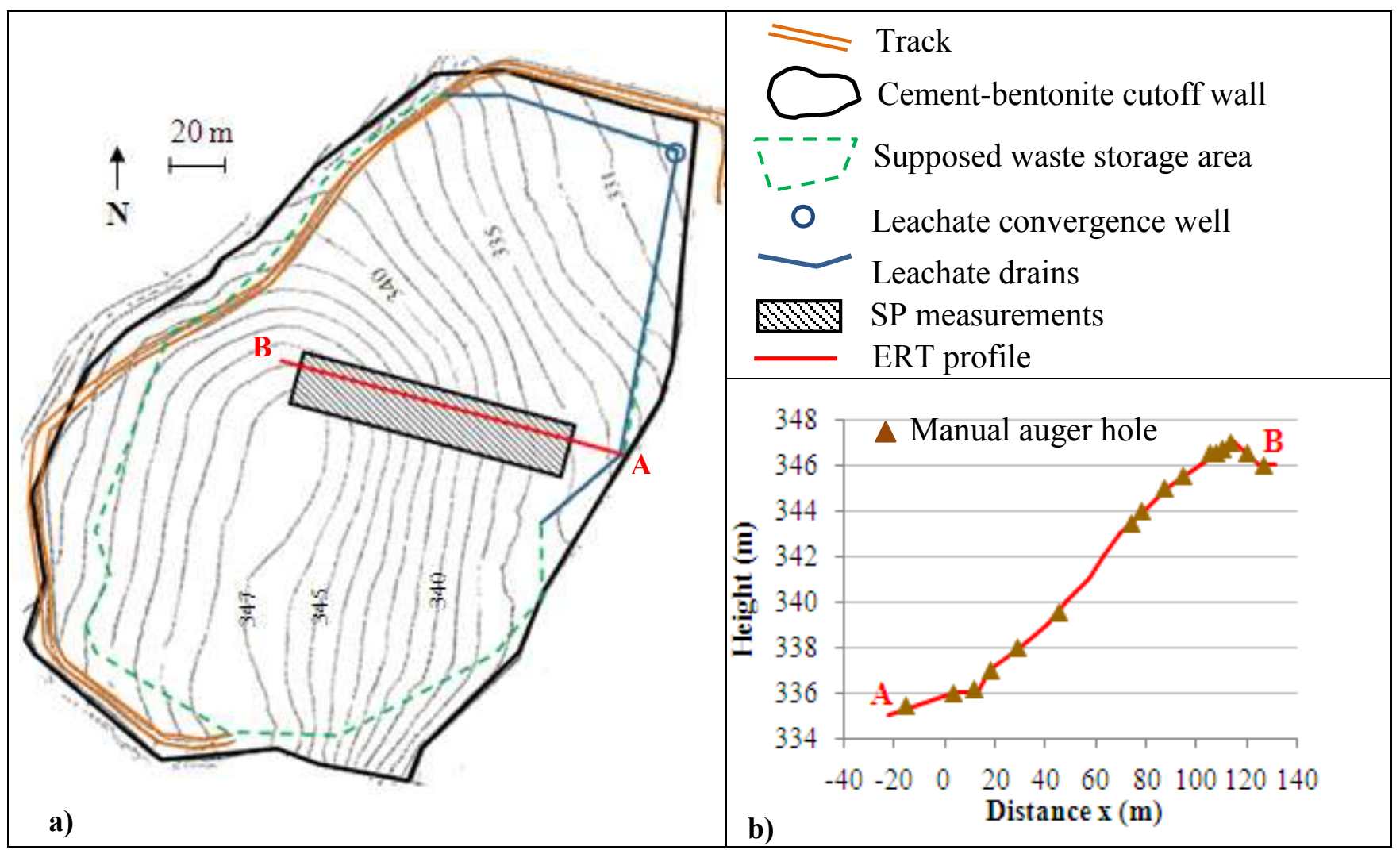


Figure 2 a) Map of the landfill with topographic lines and location of geophysical measurements b) Topography along the ERT profile named AB with location of manual auger holes

\subsection{Geophysical methods}

The Automatic Resistivity Profiling (ARPC) system uses a patented multi-electrode device connected to wheel-based electrodes which roll over the ground surface (Dabas 2009). The rolling electrodes are arranged in a trapezoid pattern. Electrical current is injected into the ground by a pair of electrodes and resistance is measured by three other pairs of electrodes acting as potential dipoles (Fig. 3). The different electrode spacings between injection dipole and potential ones (respectively $0.5,1.0$ and $2.0 \mathrm{~m}$ ) allow simultaneous acquisition of apparent electrical resistivity data at three increasing investigation depths.

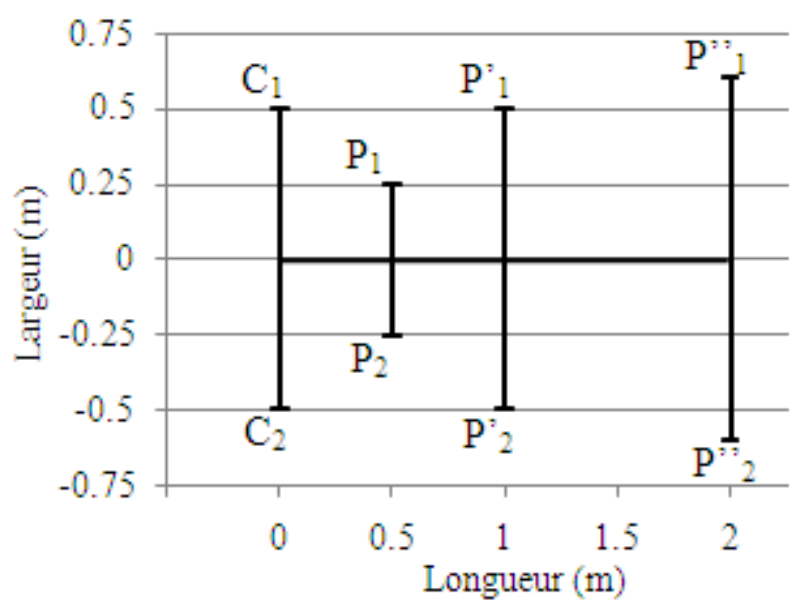

Figure 3 Sketch of electrodes configuration used in the ARP system. $C_{1}$ and $C_{2}$ are current injection electrodes, $P_{1}$ and $P_{2}, P_{1}^{\prime}$ and $P{ }_{2} P{ }^{\prime}{ }_{1}$ and $P{ }^{\prime}{ }_{2}$ are potential measurements electrodes.

The system includes a differential GPS and is towed by a quad bike for quicker data acquisition. Site coverage follows a grid of parallel survey lines in a bi-directional 
pattern, guided by on-board navigation. Data is plotted as apparent resistivity maps for each channel. The ARPC system (Dabas 2009) is already used in archeological surveys (Papadopoulos et al. 2009; Campana and Dabas 2011), viticultural farming (Costantini et al. 2009; Ghinassi et al. 2010) and geology in an alluvial landscape (Tye et al. 2011). Because of its speed of data acquisition it would seem to be interesting to carry out it on landfills.

ARP measurements were performed in November 2009 on the overall landfill with a $1 \mathrm{~m}$ line spacing. The survey lasted about six hours, with a speed quad of $10 \mathrm{~km}$ per hour and a measurement each $0.1 \mathrm{~m}$. Data processing involved a spline interpolation on a $0.5 \mathrm{~m}$ regular mesh.

The Self-Potential (SP) method consists in measuring the natural electrical potential at the ground surface. The SP signals are associated with different polarization mechanisms occurring naturally in the ground (e.g. Jouniaux et al. 2009). The main sources are due to water fluxes in the vadose zone (Thony et al. 1997; Doussan et al. 2002; Linde et al. 2011) and/or saturated zone (Rizzo et al. 2004; Maineult et al. 2008; Bolève et al. 2009) through the electrokinetic coupling, gradients in chemical potential through the electrochemical coupling and redox processes (Maineult et al. 2004; Naudet and Revil 2005). These sources constitute the primary sources of the SP signals. The secondary sources are due to electrical resistivity contrasts of the subsurface. Therefore, a detailed knowledge of the electrical resistivity distribution is necessary to accurately modelize SP responses. The multiplicity of sources mirrors the main limitation of the SP method as many different processes contribute to the measured response. In this study, we expect to detect three main sources : electrokinetic effect and electrical 
contrasts in zones where cracks in the cover facilitate surface water infiltration, and oxido-reduction reactions due to waste biodegradation.

The equipment used for the measurement were a MX20 Metrix voltmeter with a high input impedance $\left(\sim 10^{8} \Omega\right)$, one cable reel and two non-polarisable $\mathrm{Pb} / \mathrm{PbCl}_{2}$ electrodes (Petiau 2000). The SP survey was carried out just after ARP measurements and was focused on the area delimited by the black rectangle, characterized by a high electrical resistivity contrast on the slope (Fig. 5). Measurements were performed between a roving electrode and a fixed electrode at a base station. The measurement mesh was $5 \mathrm{~m}$ square with profiles oriented from West North-West to East South-East. To ensure uniform ground contact between the electrodes, small holes were dug at each station and filled with bentonite mud. The SP signal at each measurement point was stable, the maximum variation was estimated at more or less $1 \mathrm{mV}$. During the mapping, several SP measurements were performed with the two electrodes placed in the base station hole in order to make a linear drift correction of the data.

The Electrical Resistivity Tomography (ERT) is based on the injection of electrical current into the ground followed by the measurement of resulting potential differences between a set of electrodes. This method has already been used to locate seepage or erosion in dams (Johansson and Dahlin 1996; Sjödhal et al. 2008) or to map landfill geometry (Reynolds and Taylor 1996; Bernstone and Dahlin 1997). The ERT applications has been also applied to estimate the soil water content (Michot et al. 2003; Schwartz et al. 2008; Brunet et al. 2010) or to characterize the soil heterogeneity (Samouëlian et al. 2003; Besson et al. 2004) and its compaction (Abu-Hassanein et al. 1996). 
As it is time-consuming to perform ERT measurements on the whole cover of the landfill, a specific zone observed with the ARP was selected to carry out the ERT profile (see location on Fig. 2). Measurements were performed in June 2010 thanks to 72 electrodes installed every $0.5 \mathrm{~m}$ connected to a Syscal Pro resistivimeter. Different arrays, defined according to measurements formerly carried out on an experimental site, were at first implemented on a test panel in order to choose the appropriate acquisition parameters. Since the dipole-dipole array has given good results on the experimental site (Genelle et al. 2011b), especially in the detection of a $0.1 \mathrm{~m}$ wide crack by a pronounced electrical contrast with the surrounding gravelly-clay material, it was consequently used on this site with a roll-along technique (24 electrodes overlap between each panel). In order to reach the waste depth and knowing that the theoretical thickness of the cover is $2.3 \mathrm{~m}$, measurements were performed using two different sequences on the $\mathrm{AB}$ profile without moving electrodes : the first sequence with a distance between potential electrodes "a" equals to $0.5 \mathrm{~m}$ and the second one with a distance "a" equals to $1.0 \mathrm{~m}$ (Fig. 4). These two sequences provide data until investigation depths of 2.3 and $5.7 \mathrm{~m}$ respectively.

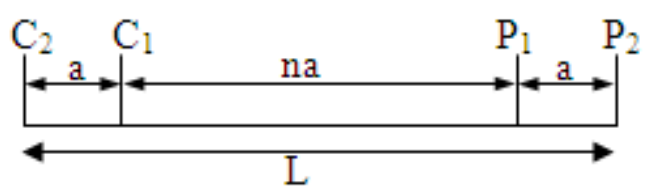

Figure 4 Sketch of electrodes configuration for dipole-dipole array used for the ERT measurements. $C_{1}$ and $C_{2}$ are current injection electrodes, $P_{1}$ and $P_{2}$ are potential measurements electrodes.

Data inversion was carried out with the RES2DINV software (Loke 2010) using 2D regularized least square optimization method with robust (L1-norm) model constraints inversion (Loke et al. 2003) combined with a model refinement. Due to a high electrical resistivity contrasts on site, the L1-norm was more adapted as it produces 
a more accurate resistivity pattern with sharper boundaries than with the smoothness constrained L2-norm.

\subsection{Manual auger holes}

Sixteen manual auger holes were dug along the ERT profile in order to improve the knowledge of the cover in this part of the landfill (Fig. 2). The description of the cover materials was done macroscopically and their lithology chosen according to the more or less ratio of sand and clay estimated qualitatively with the help of experienced geologists. The GCL condition (undamaged or not) was put in connection with the more or less resistance of the manual auger. As the GCL is known to be mechanically very resistant, when it was crossed without any resistance, the GCL was defined as "very damaged" and most of the time the presence of textile fibers or bentonite was observed in samples extracted from the auger. When it was not crossed, we assumed that it was in "good" condition e.g. less damaged.

\section{Results}

\section{- ARP measurements}

The three maps obtained with the 0.5, 1.0 and $2.0 \mathrm{~m}$ electrode spacing (Fig. 5) show apparent electrical resistivity variations between 10 and $200 \Omega$.m. The spatial layout of electrical resistivities can be divided into four areas which differently behave. The first area, located in the north part of the landfill, gathers high electrical resistivities 
(more than $70 \Omega . \mathrm{m}$ ) whatever the electrode spacing. The second area, focused on the south part of the landfill, brings together all the places where apparent electrical resistivity decreases with the electrode spacing. This behavior may be linked with the theoretical cover composed of sandy materials upon clayey ones (Fig. 1).

The third area shows low resistivities $(<40 \Omega . \mathrm{m})$ on the $0.5 \mathrm{~m}$ electrode spacing, resistivities that tend to decrease with the increasing investigation depth. It could result, among a lot of other causes, from the presence of a higher clay content in the shallow cover materials. Finally, the fourth area is pinpointed on the north and the east boundaries of the landfill in a thin and straight area where electrical resistivity values are the lowest with the three electrode spacings. Their delimitation corresponds to the zone between leachate drains and the cutoff wall (Fig. 2). Thus, this saturated area at the foot of slope, outside the waste cells, can be due to the concentration of water fallen during the seven days before the survey (accumulation equals to $19 \mathrm{~mm}$ ).

These observations underline the heterogeneity of the cover that can be either due to the materials itself (more or less clayey materials) or to variation of compaction, water content, weathering, lithology and a more or less damaged GCL.

The area delimited by the black rectangle on Figure 5, where a high apparent electrical resistivity contrast can be seen on the slope, is the zone where SP measurements were performed in order to improve the knowledge of the cover in this part of the landfill. 


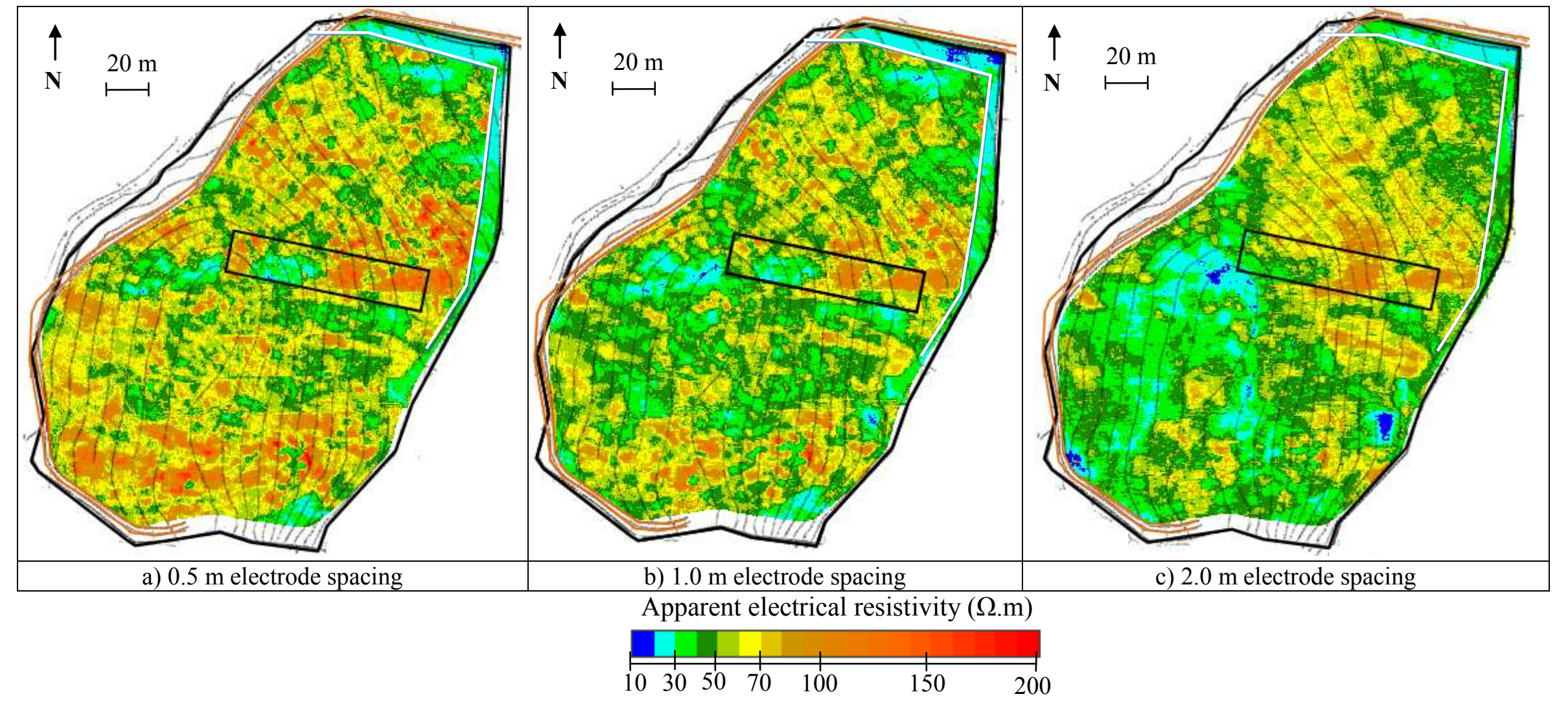

Figure 5 The three apparent electrical resistivity maps obtained with the ARP with the 0.5 m electrode spacing (a), the 1.0 m electrode spacing (b) and the 2.0 m electrode spacing (c). The SP measurement area is delimited by the black rectangle. The location of leachate drains are represented by white lines. 
- SP measurements

Figure 6 displays the five SP profiles oriented East South-East to West NorthWest on the black rectangle seen on Figure 5. The SP signal ranges from -81 to +42 $\mathrm{mV}$, with a similar behavior on each profile. Based on the signal dynamic, three different zones have been defined. Zone A, at the foot of the landfill, is marked by positive SP values (from +2 and $+42 \mathrm{mV}$ ). Zone $\mathrm{B}$ is characterized by a rather stable signal with about $70 \%$ of values contained between -10 and $+10 \mathrm{mV}$. Zone $\mathrm{C}$, located at the top of the landfill, shows a sharp decrease of SP signal (until $-81 \mathrm{mV}$ on the profile $\mathrm{y}=5 \mathrm{~m}$ ) followed by an increase of SP.

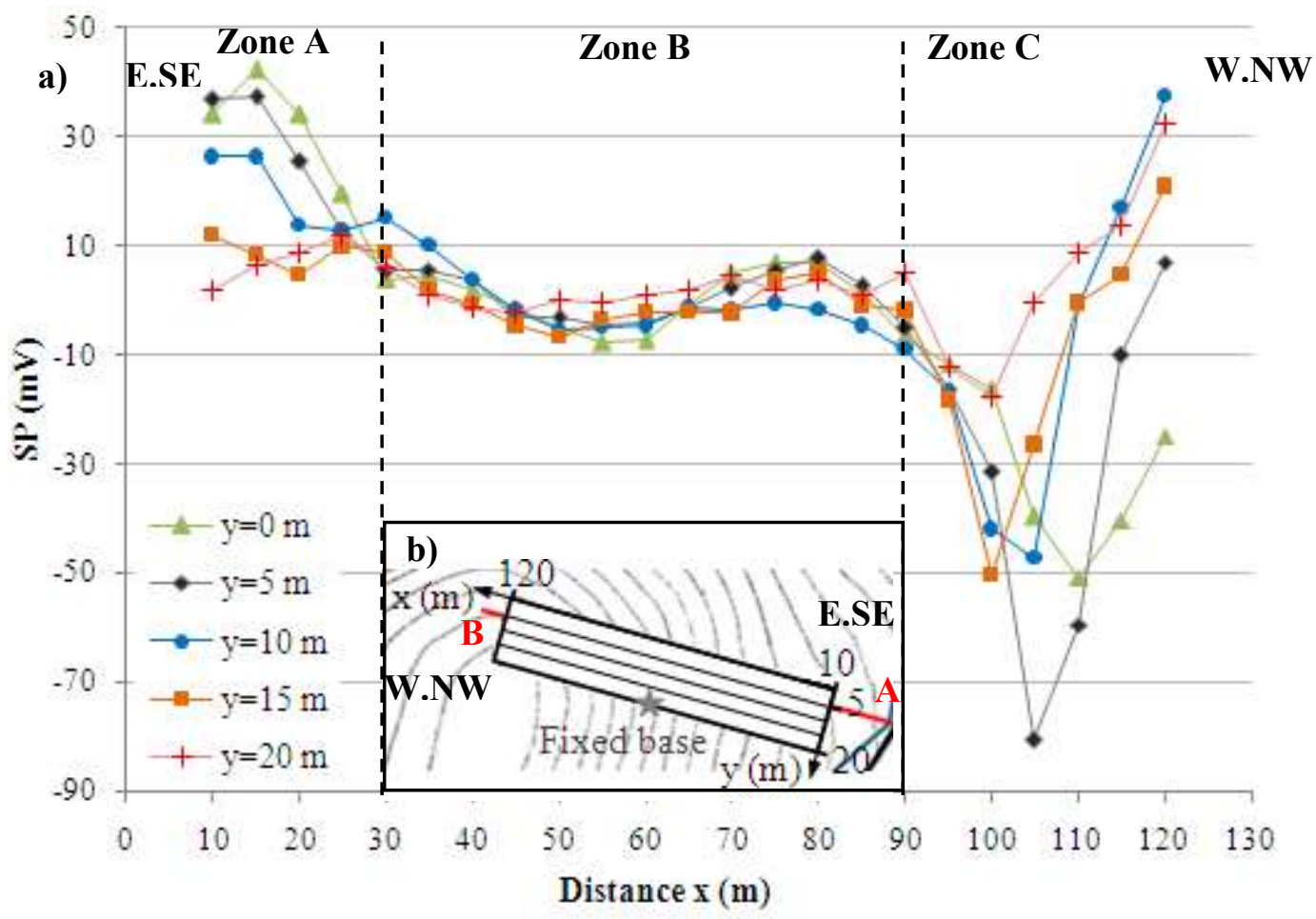

Figure 6 a) East South-East to West NorthWest profiles b) Location of the SP profiles (black lines) and the ERT profile (red line AB)

Since measurements along the profile $\mathrm{y}=5 \mathrm{~m}$ show the most variation of SP signal, an ERT profile was performed on the same location. 


\section{- ERT measurements}

The two ERT profiles (measurements acquired with $\mathrm{a}=0.5 \mathrm{~m}$ and $\mathrm{a}=1.0 \mathrm{~m}$ ) highlight electrical resistivity variations between 0.5 and $400 \Omega$.m, not only laterally but also vertically (Fig. 7). The deeper model resistivity ERT $\mathrm{a}_{\mathrm{a}}$ clearly shows the presence of low resistivity values ( $<4 \Omega$.m symbolized by grey color) at each end of the profile (respectively at about -2.3 and $-1.3 \mathrm{~m}$ deep). These low electrical resistivity values would indicate the occurrence of waste, closer to the surface at the top of the landfill where the cover thickness is thinner than the theoretical one (Fig. 1). On the central part of the model resistivity, the waste are not seen on the model resistivity and appears to be deeper.

The two model resistivity display a different spatial layout of electrical resisitivity above waste, particularly between 5 and $25 \mathrm{~m}$ of the origin of the profile : the model resisitivity $\mathrm{ERT}_{\mathrm{a}}$ displays two cover layers (Fig. 7 a) whereas the $\mathrm{ERT}_{\mathrm{b}}$ shows three layers (Fig. 7 b). Moreover, the waste depth is lower on the model resistivity $\mathrm{ERT}_{\mathrm{b}}$ than on the $\mathrm{ERT}_{\mathrm{a}}$. The waste depth estimated on the $\mathrm{ERT}_{\mathrm{b}}$ is more in accordance with the auger holes dug along the $\mathrm{AB}$ profile. However, we can note that it exist a small difference (less than $10 \%$ ) between the waste depth estimated on $\mathrm{ERT}_{\mathrm{b}}$ and their real depth at the location of the most part of the auger holes. It is probably related to the thickness inversion model blocks.

The central zone (between 30 and $90 \mathrm{~m}$ ) displays the highest electrical resistivity values from 1 to $2 \mathrm{~m}$ deep, especially between 32 and $60 \mathrm{~m}(140<\rho<450 \Omega . \mathrm{m})$. According to the theoretical log of the cover (Fig. 1), these values would be the signature of the GCL, which is normally present at a $1.1 \mathrm{~m}$ depth over the whole landfill and then should be observed on the entire profile. Nevertheless, measurements performed on the 
experimental site (Genelle et al. 2011a) on a cover made of an undamaged and unsaturated GCL (6 $\mathrm{mm}$ thick) have shown very high electrical resistivity values ( $\sim 4000$

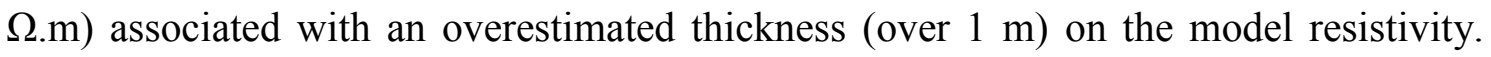
That's why we assume that lower electrical resistivity values $(\rho<140 \Omega . m)$ observed on site should be explained by a saturated and/or damaged GCL. In order to check this hypothesis, manual auger holes and forward modeling have been made.

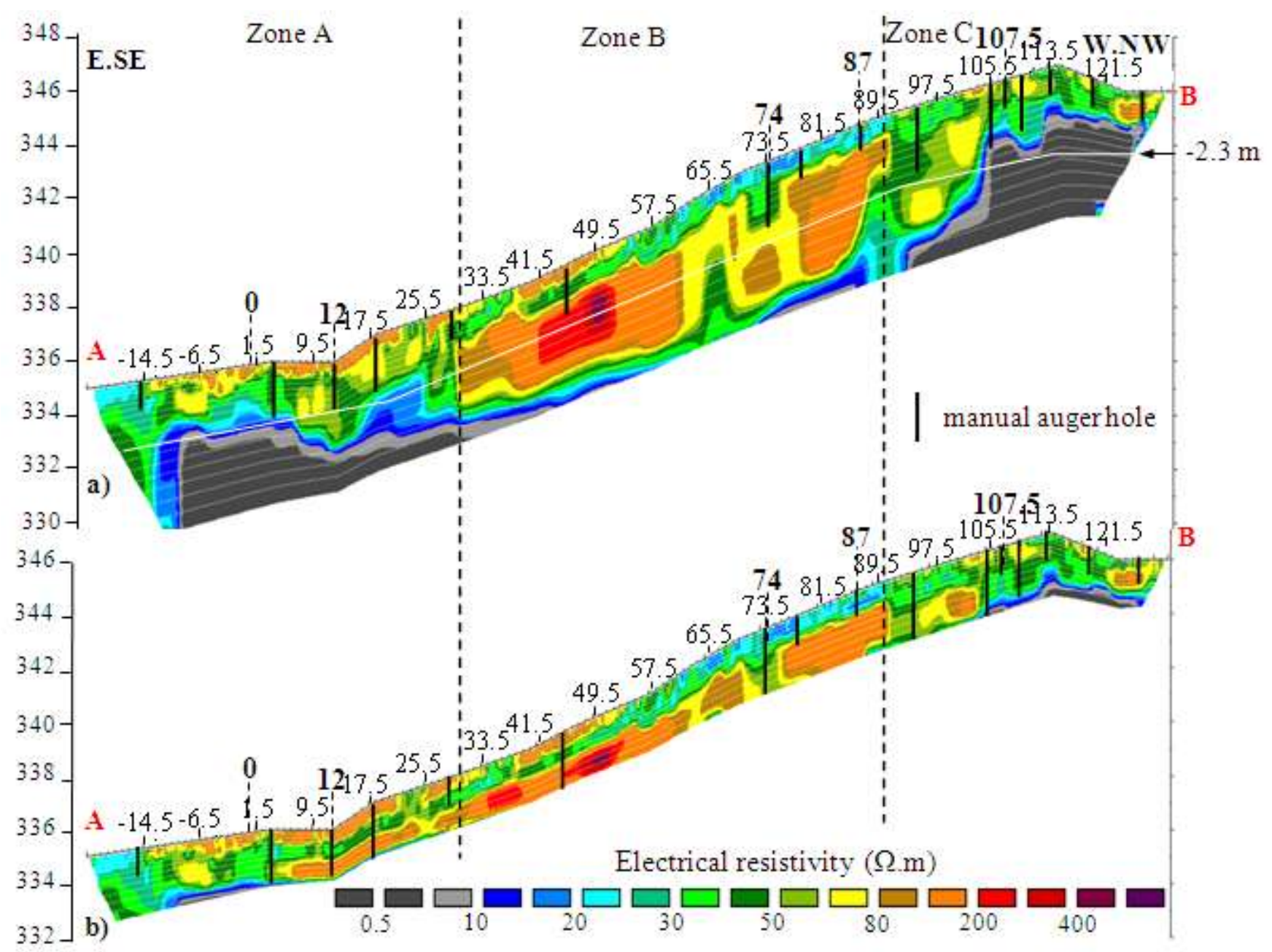

Figure 7 Model resistivity of the ERT profile and location of manual auger holes

a) $E R T_{a}$ : dipole-dipole array obtained with $a=1.0 \mathrm{~m}$ (investigation depth $=5.7 \mathrm{~m}$; Iteration 5 Abs error $=1.80 \%)$ b) $E R T_{b}:$ dipole-dipole array obtained with $a=0.5 \mathrm{~m}$ (investigation depth $=2.3 \mathrm{~m}$; Iteration $5-$ Abs error $=0.94 \%$ ). 
- Manual auger holes : comparison with ERT

To try to explain these electrical resistivity variations, 16 auger holes (symbolized by black lines on Fig. 7) were dug along the ERT profile. The auger holes put in evidence the variability of materials (nature, thickness) used for covering waste all along the ERT profile. Moreover, geodrain theoretically present at $-1.3 \mathrm{~m}$ deep was found only four times on the height auger holes performed until a depth between -1.7 and $-2.1 \mathrm{~m}$. Four of auger holes, chosen in areas of electrical resistivity contrasts previously observed on the model resistivity, are displayed on Figure 8b. They show different cover compositions met in the field. Vertical electrical resistivity values extracted from the model resistivity $\mathrm{ERT}_{\mathrm{b}}$ and located at the same places of these four auger holes are plotted on Figure 8a for comparison.

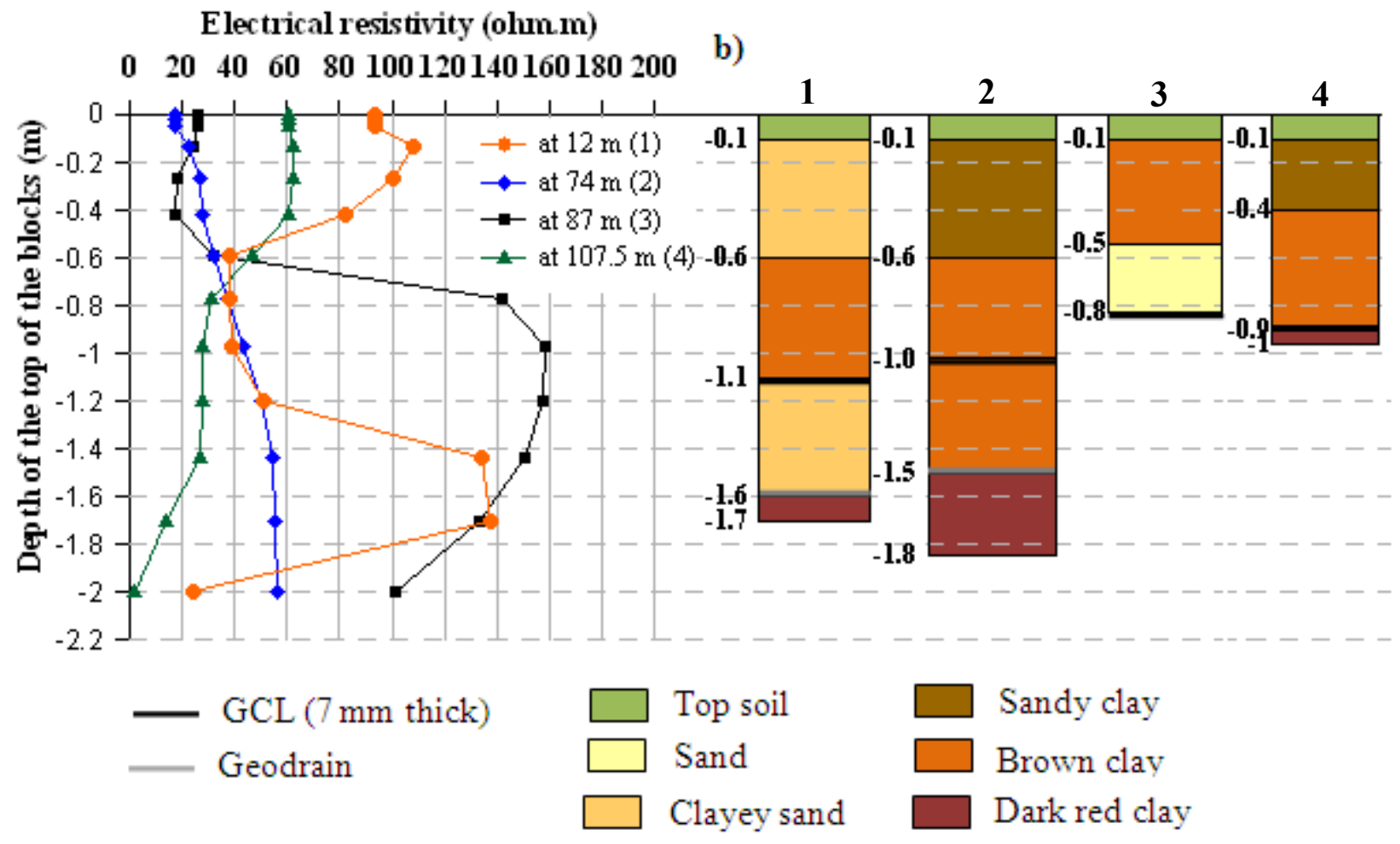

Figure 8 a) Vertical electrical resistivity values extracted from the model resistivity $E R T_{b}$ b) Description of four auger holes located along the ERT profile. 
At first, one can see that at the location of the three auger holes for which the GCL was crossed $(1,2,4)$, the thickness cover is smaller than the theoretical one because waste mixed with dark red clay were found at about $-1.6 \mathrm{~m}$ deep at $12 \mathrm{~m}$ (1), at $-1.5 \mathrm{~m}$ deep at $74 \mathrm{~m}(2)$ and only at $-1 \mathrm{~m}$ deep at $107.5 \mathrm{~m}$ (4) whereas they should be reached from $2.3 \mathrm{~m}$ deep (Fig. 1). Then, the material just above the GCL identified as brown clay at these three auger holes, whereas it was sand at $87 \mathrm{~m}(3)$, is well characterized by an electrical resistivity of about $35 \Omega . \mathrm{m}$ on the vertical profiles. Different lithology exist in the upper part of the cover : clayey sand at $12 \mathrm{~m}$ is characterized by high electrical resistivity $(\rho \sim 100 \Omega . \mathrm{m})$, sandy clay at 74 and $107.5 \mathrm{~m}$ by a resistivity all the more so low that the sand content is small in the material (here values between 20 and $60 \Omega . \mathrm{m}$ ) and brown clay at $87 \mathrm{~m}$. Even if the nature of materials above the GCL is not the same on these four auger holes, we can note that the thickness of the two first cover layers is close to the theoretical one, with a GCL in the right place. The main difference between the four auger holes occurs at the GCL's depth, between 0.8 and $-1.1 \mathrm{~m}$ deep : electrical resistivity increases until $160 \Omega . \mathrm{m}$ at $87 \mathrm{~m}$ from $-1.6 \mathrm{~m}$ deep and $140 \Omega . \mathrm{m}$ at $12 \mathrm{~m}$ from $-1.2 \mathrm{~m}$ deep. At the two other places, electrical resistivity at these depths remains lower than $60 \Omega . m$.

To explain these different behaviors, we have computed several forward modelings with RES2MOD. As the cover composition at the auger hole located at $12 \mathrm{~m}$ is the closest to the theoretical one, we have reproduced it using the electrical resistivity variations met at this location (Tab. 1). Several cases have been studied but here we present only two of them that are considered to be the most representative. A first modeling was created with an unsaturated and undamaged GCL ( $\rho=8400$ S.m and 0.1 $\mathrm{m}$ thick) that corresponds to a value of at least $120000 \Omega . m$ measured on laboratory on 
a $7 \mathrm{~mm}$ thick undamaged GCL (in applying the equivalence principle). A second modeling was made with a more saturated and torn GCL $(\rho=840 \Omega . \mathrm{m}$ and $0.1 \mathrm{~m}$ thick).

\begin{tabular}{|c|c|c|}
\hline Thickness layers $(\mathrm{m})$ & Forward modeling 1 & Forward modeling 2 \\
\hline $0-0.6$ & \multicolumn{2}{|c|}{ Clay sand $(102 \Omega . \mathrm{m})$} \\
\hline $0.6-1.1$ & \multicolumn{2}{|c|}{ Clay $(33 \Omega . \mathrm{m})$} \\
\hline $1.1-1.2$ & $\begin{array}{c}\text { GCL }(8400 \Omega . \mathrm{m}) \\
\text { Equivalent to } 120000 \Omega . \mathrm{m} \\
\text { for } 7 \mathrm{~mm} \text { thick }\end{array}$ & $\begin{array}{c}\text { Gquivalent to } 12 . \mathrm{m}) \\
\text { for } 7 \mathrm{~mm} \text { thick }\end{array}$ \\
\hline $1.2-1.6$ & \multicolumn{2}{|c|}{ Saturated clay sand $(50 \Omega . \mathrm{m})$} \\
\hline$>1.6$ & \multicolumn{2}{|c|}{ Waste $(4 \Omega . \mathrm{m})$} \\
\hline
\end{tabular}

Table 1 Electrical resistivity and thickness of cover materials layers chosen for forward modelings.

In order to compare at best the data of these two forward modelings with the measurements on site along the ERT profile, they have been inverted using the same kind of inversion, that is to say robust model constraints combined with a model refinement (Fig. 9).

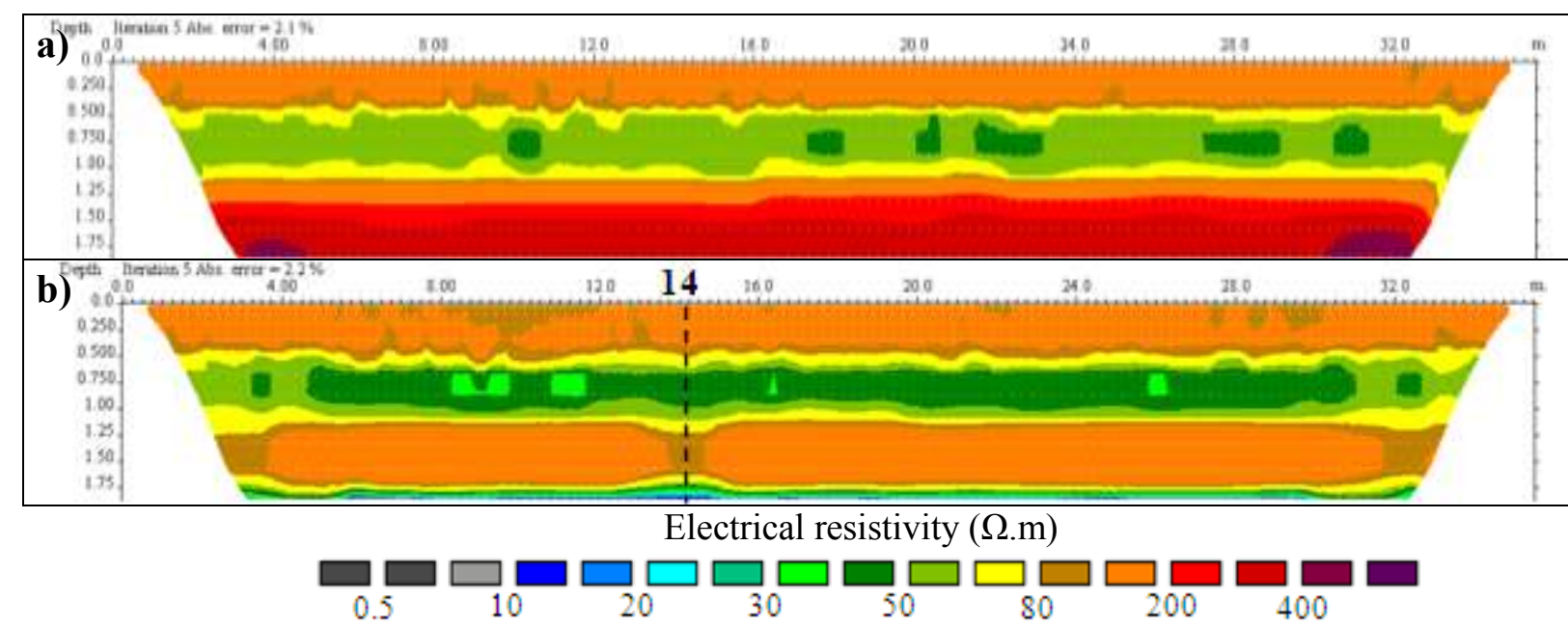

Figure 9 a) Model resistivity resulted from the inversion of the forward modeling 1

(with an undamaged and unsaturated GCL) b) Model resistivity resulted from the inversion of the forward modeling 2 (with a saturated GCL and a $0.125 \mathrm{~m}$ wide tear at the vertical of $14 \mathrm{~m}$ ).

Both the model resistivity resulted from the inversion of the forward modelings show an overestimated thickness of the GCL from $-1.1 \mathrm{~m}$ deep. In the case of the undamaged 
GCL, electrical resistivities are higher than 200 S.m (Fig. 9 a). These values have been observed on the central part of the model resistivity (until $450 \Omega . m$ ). In the case of the more saturated GCL, electrical resistivities are about 100 S.m (Fig. 9 b). Moreover, a decrease of resistivity $(\rho \sim 80 \Omega . m)$ is seen at the GCL's depth at the vertical of $14 \mathrm{~m}$, at the place of the tear previously created. Furthermore, we can note that low resistivities are seen in deep even in the part where the GCL was not torn. They are linked with the materials present below the GCL.

These modeling let us link the electrical resistivity variations previously seen on the model resistivity at the GCL's depth with its damaging condition, especially at the location of the three auger holes 1,2 and 4 described on Figure 8. Thus, on the one hand, the lack of high electrical resistivity from the GCL's depth at the auger holes 2 and 4 means that the GCL is damaged and/or saturated. On the other hand, electrical resistivities reaches $120 \Omega . \mathrm{m}$ at the auger hole 1 and seems to be representative of a less damaged and/or saturated GCL.

Finally, the variation of electrical resistivity seen on the model resistivity ERT $_{b}(a=0.5$ m) until the GCL's depth can be related to different nature of cover materials for all the manual auger holes. Moreover, the use of forward modeling has demonstrated the link of electrical resistivity variations at $-1.1 \mathrm{~m}$ depth with the damaging condition of the GCL.

\section{Discussion}

In this part, we have compared more particularly the ARP and ERT measurements in order to know if similarities exist between them. Then, we have 
studied together the measurements acquired by the three geophysical methods (ARP, ERT and SP) along the AB profile.

Even if the geophysical methods were not carried out simultaneously on the landfill, we attempt to compare in a first time apparent electrical resistivities obtained with the ARP and the ERT along the AB profile (Fig. 10) thanks to statistical methods.

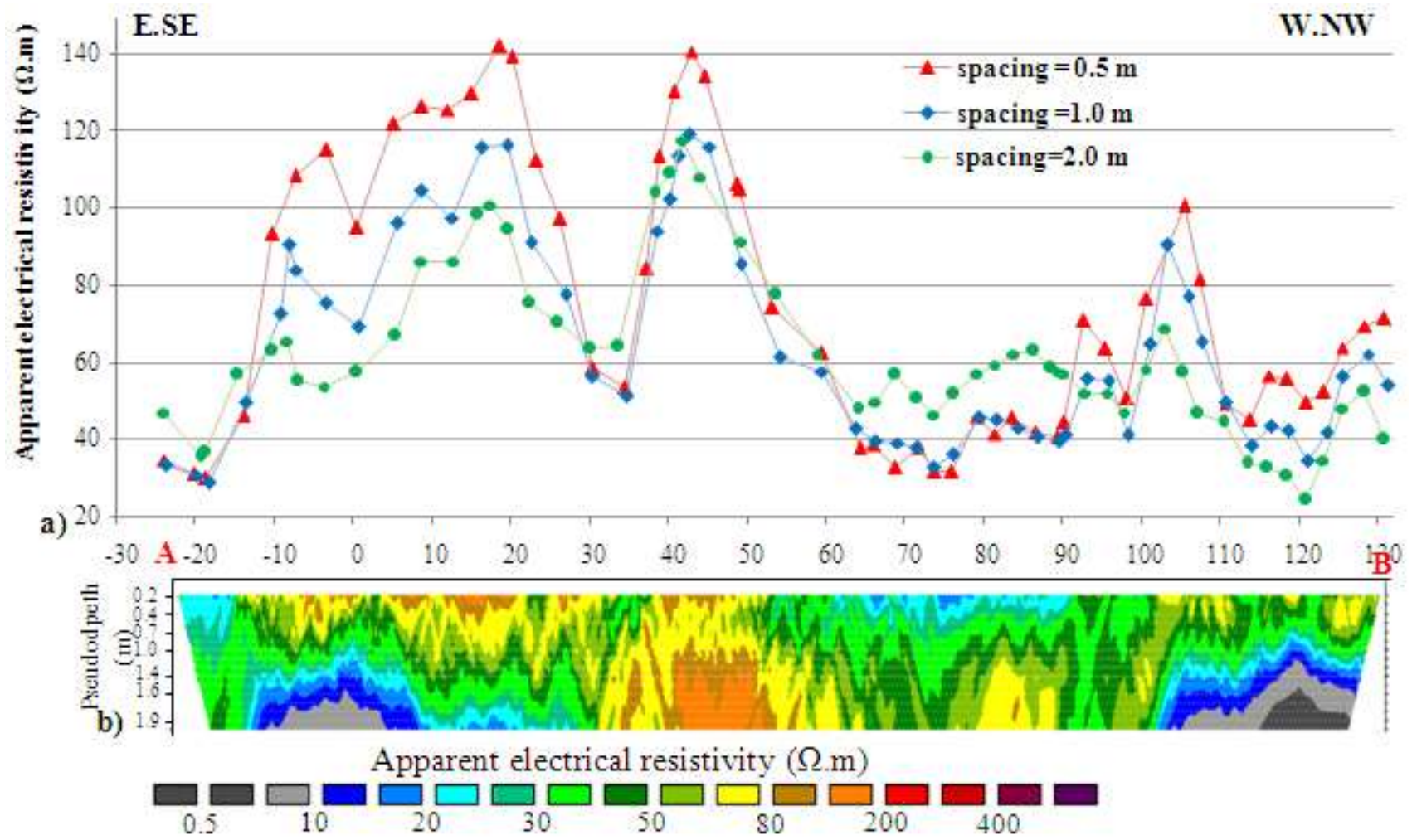

Figure 10 a) Apparent electrical resistivity extracted from ARP measurements along the AB profile b) Apparent electrical resistivity pseudosection of the $E R T_{b}$ profile (dipole-dipole array obtained with $a=0.5 \mathrm{~m}$ ).

The apparent electrical resistivity provided by the ARP survey displays similar variations along the $\mathrm{AB}$ profile whatever the electrode spacing (Fig. $10 \mathrm{a}$ ) : values are globally higher than $80 \Omega . \mathrm{m}$ from the beginning of the profile to $60 \mathrm{~m}$ while they are lower than $60 \Omega . \mathrm{m}$ in the second part of the profile. The apparent electrical resistivity 
obtained with the ERT shows globally the same resistivity range on the shallow part of the pseudosection. The values in the deep part of the pseudosection (from about $1.0 \mathrm{~m}$ deep) are lower than these seen on the ARP 2.0 m electrode spacing, especially at each end of the profile.

On the most part of the profile, ARP apparent electrical resistivity tends to decrease with the increasing electrode spacing. For example, at $12 \mathrm{~m}$ the electrical resistivity respectively equals to $122 \Omega . \mathrm{m}$ and $82 \Omega . \mathrm{m}$ for the ARP 0.5 and $2.0 \mathrm{~m}$ electrode spacings. An opposite behavior can be seen between 65 and $90 \mathrm{~m}$ : apparent electrical resistivity are higher with the ARP 2.0 m electrode spacing, about $60 \Omega . m$ compared to $40 \Omega . m$ with the two others electrode spacings. On the pseudosection, electrical contrasts between the shallow material and the underlying one is more pronounced : at $12 \mathrm{~m}$, resistivities decrease from 150 to $40 \Omega . \mathrm{m}$ with depth whereas, in the area between 65 and $90 \mathrm{~m}$, they are contained between 15 and $40 \Omega . \mathrm{m}$. These two different vertical variations of apparent electrical resistivity can be linked with the variability of cover materials. For instance, the shallow material at $74 \mathrm{~m}$ is characterized by higher clay content than it is at the same depth at $12 \mathrm{~m}$ (Fig. 8). The lowest apparent electrical resistivity values $(<60 \Omega . \mathrm{m})$ on the ARP $2.0 \mathrm{~m}$ electrode spacing are focused at the end of the profile where the cover is thin. In this zone, the pseudosection also shows lower apparent electrical resistivity with increasing depth, in connection with the influence of waste.

In order to investigate relationships between ARP and ERT data, we have computed the Pearson correlation coefficient for all pairs of the twenty-three variables corresponding to the resistivity acquired with the three ARP devices (electrode spacing 0.5, 1.0 and $2.0 \mathrm{~m}$ - Fig. 3) and the twenty configurations characterized by a different 
distance L of the dipole-dipole array (ERT) (Fig. 4). This correlation matrix has been calculated for a set of 23 per 29 values of resistivity sampled each $5 \mathrm{~m}$ between -15 and $125 \mathrm{~m}$ along the $\mathrm{AB}$ profile (Tab. 2).

\begin{tabular}{|c|c|c|c|c|c|c|c|c|c|c|}
\hline $\mathbf{N}^{\circ}$ variable & 1 & 2 & 3 & 4 & 5 & 6 & \multicolumn{2}{|c|}{$7-21$} & 22 & 23 \\
\hline \multirow{2}{*}{ Variable } & $\begin{array}{c}\text { ARP } \\
(0.5)\end{array}$ & $\begin{array}{c}\text { ARP } \\
(1.0)\end{array}$ & $\begin{array}{c}\text { ARP } \\
(2.0)\end{array}$ & $\begin{array}{c}\text { ERT } \\
(1.5)\end{array}$ & $\begin{array}{c}\text { ERT } \\
(2.0)\end{array}$ & $\begin{array}{c}\text { ERT } \\
(2.5)\end{array}$ & $\ldots \ldots$ & $\ldots$ & $\begin{array}{c}\text { ERT } \\
(9.0)\end{array}$ & $\begin{array}{c}\text { ERT } \\
(9.5)\end{array}$ \\
\hline ARP $(0.5)$ & 1.00 & 0.98 & 0.74 & $\mathbf{0 . 8 4}$ & $\mathbf{0 . 8 4}$ & 0.76 & $\ldots$ & $\ldots$ & -0.04 & -0.04 \\
\hline ARP $(1.0)$ & 0.98 & 1.00 & 0.80 & 0.79 & $\mathbf{0 . 8 0}$ & 0.75 & $\ldots$ & $\ldots$ & 0.06 & 0.07 \\
\hline ARP $(2.0)$ & 0.74 & 0.80 & 1.00 & 0.49 & 0.52 & 0.55 & $\ldots$ & $\ldots$ & 0.52 & 0.53 \\
\hline ERT $(1.5)$ & 0.84 & 0.79 & 0.49 & 1.00 & 0.92 & 0.75 & $\ldots$ & $\ldots$ & -0.20 & -0.20 \\
\hline ERT $(2.0)$ & 0.84 & 0.80 & 0.52 & 0.92 & 1.00 & 0.86 & $\ldots$ & $\ldots$ & -0.26 & -0.26 \\
\hline ERT $(2.5)$ & 0.76 & 0.75 & 0.55 & 0.75 & 0.86 & 1.00 & $\ldots$ & $\ldots$ & -0.25 & -0.25 \\
\hline & $\ldots$ & $\ldots$ & $\ldots$ & $\ldots$ & $\ldots$ & $\ldots$ & 1.00 & $\ldots$ & 0.02 & 0.01 \\
\cline { 2 - 11 } & $\ldots$ & $\ldots$ & $\ldots$ & $\ldots$ & $\ldots$ & $\ldots$ & $\ldots$ & 1.00 & 0.99 & 0.98 \\
\hline ERT $(9.0)$ & -0.04 & 0.06 & 0.52 & -0.20 & -0.26 & -0.25 & 0.02 & 0.99 & 1.00 & 0.99 \\
\hline ERT $(9.5)$ & -0.04 & 0.07 & 0.53 & -0.20 & -0.26 & -0.25 & 0.01 & 0.98 & 0.99 & 1.00 \\
\hline
\end{tabular}

Table 2 Correlation matrix computed between apparent electrical resistivity obtained with the ARP and the ERT.

The correlation coefficient is a measurement of how two variables are related. High positive values indicate possible relations among pairs of variables. We can see in particular that the highest correlation for the ARP (0.5) and ARP (1.0) is found with the $\mathrm{L}=2.0 \mathrm{~m}$ configuration of the dipole-dipole array. Focusing our attention on the possible relation among ARP resistivity variable and ERT resistivity variable (Tab. 3), the highest correlation $(\mathrm{r}=0.87)$ is found for the $\mathrm{L}=4.0 \mathrm{~m}$ configuration of the dipole-dipole array and ARP (2.0). It means that $76 \%\left(\mathrm{r}^{2}=0.87^{2}\right)$ of the variability of the ERT resistivity is accounted by ARP (2.0) resistivity. Moreover, testing the null hypothesis $\mathrm{H}_{0}$ that the two variables are independent, shows that the null hypothesis should not be accepted, at a very high significant level $(\alpha<0.001)$. A strictly similar conclusion arises when computing the Kendall non parametric rank correlation as it has already been 
done for geophysical purposes by Gebbers et al. (2009) : the null hypothesis is respected with a statistically highly significant level ( $p$ value $<0.001)$.

\begin{tabular}{|c|c|c|c|c|c|c|}
\cline { 2 - 7 } \multicolumn{1}{c|}{} & $\begin{array}{c}\text { ARP } \\
(0.5)\end{array}$ & $\begin{array}{c}\text { ERT } \\
(1.5)\end{array}$ & $\begin{array}{c}\text { ERT } \\
(2.0)\end{array}$ & $\begin{array}{c}\text { ERT } \\
(2.5)\end{array}$ & $\begin{array}{c}\text { ERT } \\
(3.5)\end{array}$ & $\begin{array}{c}\text { ERT } \\
(4.0)\end{array}$ \\
\hline $\operatorname{ARP}(0.5)$ & 1.00 & $\mathbf{0 . 8 4}$ & $\mathbf{0 . 8 4}$ & 0.76 & 0.67 & 0.57 \\
\hline $\operatorname{ARP}(1.0)$ & 0.98 & 0.79 & $\mathbf{0 . 8 0}$ & 0.75 & 0.72 & 0.65 \\
\hline $\operatorname{ARP}(2.0)$ & 0.74 & 0.49 & 0.52 & 0.55 & $\mathbf{0 . 8 1}$ & $\mathbf{0 . 8 7}$ \\
\hline ERT $(1.5)$ & 0.84 & 1.00 & 0.92 & 0.75 & 0.46 & 0.40 \\
\hline
\end{tabular}

Table 3 Extract of the correlation matrix computed between apparent electrical resistivity obtained with the ARP and the ERT.

Table 2 and Table 3 show Pearson coefficients relating ARP and ERT measurements from the studied area; they should not be considered as universal. Nevertheless, in the present case, the ARP (2.0) is effectively the most correlated with the $\mathrm{L}=4.0 \mathrm{~m}$ configuration of the dipole-dipole array of the ERT that corresponds to a pseudodepth of about $0.87 \mathrm{~m}$ (Edwards 1977). This pseudodepth of investigation is defined as the depth where the earth above it has the same influence on the measured potential as the lower part. According to these results, we could conclude that ARP $2.0 \mathrm{~m}$ electrode spacing is not able to detect the GCL present at a $1.1 \mathrm{~m}$ depth, knowing that the Edward pseudodepth of investigation has been defined for homogeneous grounds although it is not the case in our study. Dabas et al. (2009) studied, in the case of two-layers, the depth from which the presence of a layer is not anymore detectable. Taking a detectability threshold of $10 \%$, they showed that the ARP (2.2) could be able to detect a resistive layer whose top is located between 2 and $3 \mathrm{~m}$ depth when the resistivity contrast with the upper conductive layer varies between 2 and 12. In this study, layers are still considered as homogeneous. It appears actually in our site (Fig. 10) that ARP (2.0) could detect the effect of a resistive layer between 60 and $90 \mathrm{~m}$. However, it is not the case between 35 and $60 \mathrm{~m}$ where a resistive layer has been put in evidence by TRE. We outline here the difficulty in only observing apparent electrical resistivity maps 
faced with very heterogeneous shallow fields. It confirms that the ARP is mainly influenced by the cover materials close to the surface and does not reach the GCL.

After the previous comparison between apparent electrical resistivity acquired with ARP and ERT, we have analyzed together the measurements acquired by the three geophysical methods (ARP, ERT and SP) along the AB profile.

To facilitate the comparison of these methods between 10 and $120 \mathrm{~m}$ along the $\mathrm{AB}$ profile, electrical resistivity values were regularly sampled from the model resistivity $\mathrm{ERT}_{\mathrm{b}}$ between -1.4 and $-2.0 \mathrm{~m}$ and apparent electrical resistivity values from the $2.0 \mathrm{~m}$ electrode spacing of the ARP, and then were plotted with the SP values of the $y=5 \mathrm{~m}$ profile (Fig. 11). The depths of blocks chosen for the electrical resistivity values are these characterizing at best the GCL (Fig. 8). 


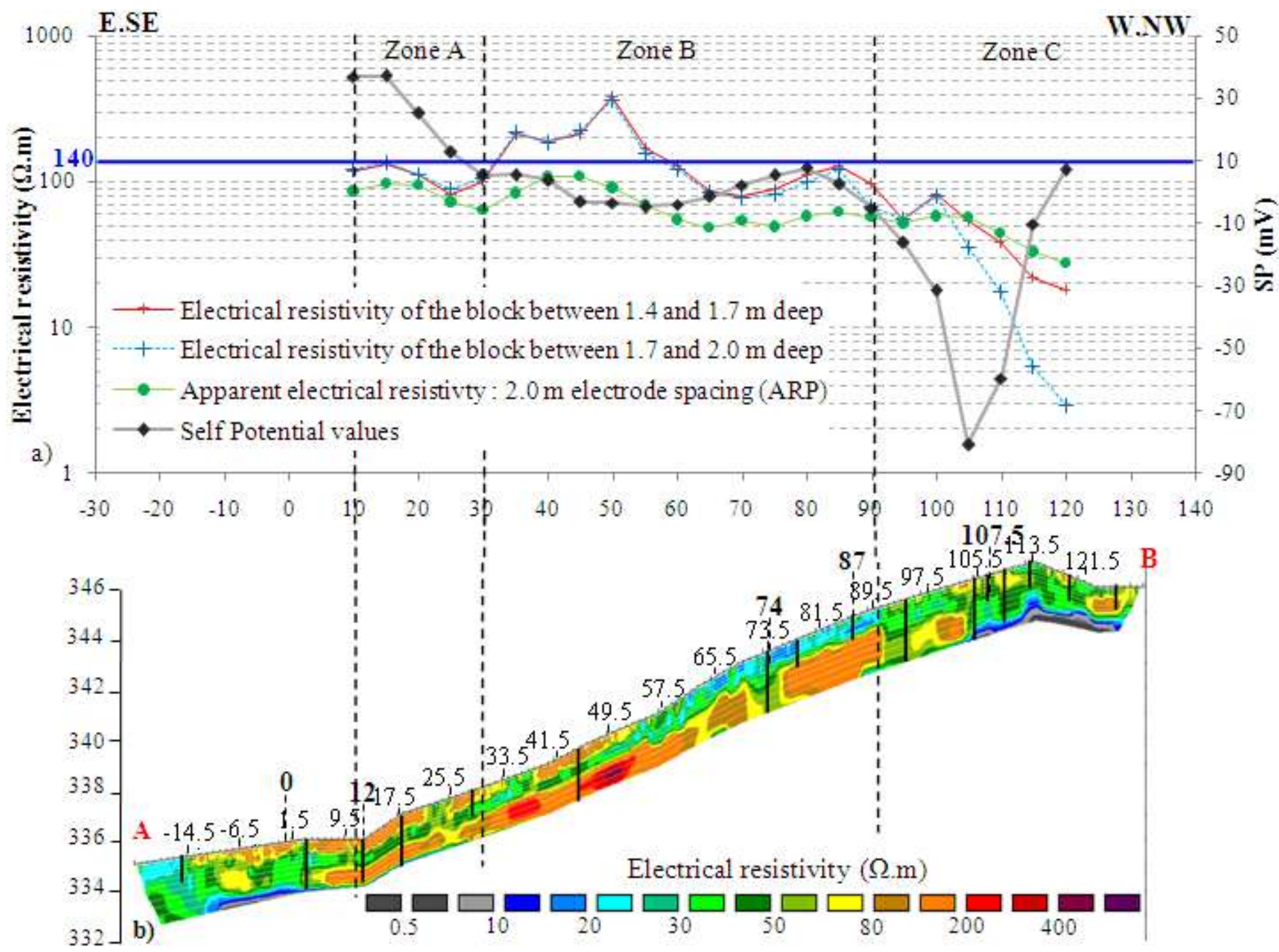

Figure 11 Comparison of the three geoelectrical methods a) Profiles showing electrical resistivity values extracted from the model resistivity ERT (obtained with $a=0.5 \mathrm{~m}$ ) at two different depths, apparent electrical resistivity values extracted from the $2.0 \mathrm{~m}$ electrode spacing of the ARP, and $S P$ profile $y=5 \mathrm{~m}$ b) Model resistivity $E R T_{b}$ of the AB profile.

The beginning of the profile shows a decrease of SP signal from +40 to $+10 \mathrm{mV}$ while ARP and ERT values, lower than $140 \Omega . \mathrm{m}$, do not reveal high variations of resistivity. On the central part of the profile (between 30 and $90 \mathrm{~m}$ ), electrical resistivity between 1.4 and $-2.0 \mathrm{~m}$ are contained between 80 and $140 \Omega . \mathrm{m}$ (with high values focused from 
30 to $60 \mathrm{~m}$ ). A similar variation of apparent electrical resistivity is observed on the ARP values. In this area, the GCL seems to be in better condition and could prevent SP signal from going through it. This assumption could explain the relative stability of the SP signal (variations from -10 to $+10 \mathrm{mV}$ ) in this part of the profile.

The end of the profile (Fig. 11) displays a decrease of electrical resistivity until $3 \Omega . \mathrm{m}$ from -1.7 to $-2.0 \mathrm{~m}$ : the waste depth, checked by manual auger holes is really closer to the surface at the top of the landfill. The apparent electrical resistivity of the $2.0 \mathrm{~m}$ electrode spacing also tends to decrease but only from $110 \mathrm{~m}$ and weakly. The SP signal also shows a great anomaly of around $-70 \mathrm{mV}$ at the top of the landfill. We can assume that this negative SP anomaly can be mainly associated with the shallow presence of biodegradation waste that are known to produce a strong negative SP signal (Naudet and Revil 2005; Arora et al. 2007). Moreover, a correlation matrix, made on the electrical resistivity (ERT, ARP) and SP, has highlighted that the maximum correlation of SP signal, equals to 0.40 , is obtained with the ARP $2.0 \mathrm{~m}$ electrode spacing. Given that electrical resistivities of the ARP $(2.0 \mathrm{~m})$ and the ERT $(\mathrm{L}=4.0 \mathrm{~m})$ are correlated to each other $(\mathrm{r}=0.87)$ whereas they are not to the SP, we can conclude that the physical phenomena influencing each method are in a certain way independent.

Finally, the high apparent electrical resistivity contrasts seen with the ARP 0.5 and 1.0 $\mathrm{m}$ electrode spacing, due to the very heterogeneous nature of cover materials, lead in a certain way to a difficult detection of the GCL with the ARP (2.0). An inversion of the ARP data would be necessary to have accurate information about the cover. Moreover, a bigger electrode spacing would allow to increase the ARP investigation depth. Finally, the ERT is not only sensitive to the nature of materials (especially the clay content) but 
also to the GCL's condition (damaged, saturated or not) and the waste depth located between -1.6 and $-0.9 \mathrm{~m}$ along the $\mathrm{AB}$ profile.

\section{Conclusion}

Three geophysical methods, the Electrical Resistivity Tomography (ERT), the Automatic Resistivity Profiling (ARPC) and the Self Potential (SP), have been applied on a French hazardous waste landfill in order to determine their ability to detect damages in the cover. Knowledge of the defect location is important because they can induce preferential water pathways and unusual increase of leachate within the waste mass.

ARP and ERT (with a=1.0 m) have together enabled to discover numerous heterogeneities unsuspected given the knowledge of the theoretical log of the cover. The ARP has highlighted lateral variations of cover materials on the overall landfill thanks to maps obtained at three different investigation depths. Apparent electrical resistivity variations have been shown to mainly correspond to different lithologies in the shallow cover materials. These high electrical contrasts in the shallow part of the cover have in a certain way prevented the detection of deeper variations at the GCL's depth. That's why the only use of the ARP is not up to date sufficient to fully understand the cover behavior because of a too much limited number of investigation depths in available instrumentation. Ideally, the addition of potential dipoles with several electrode spacings on the actual configuration of the ARP would allow to inverse all the data, providing a more reliable result.

A more detailed analysis performed with the ERT with a 0.5 m electrode spacing in spite of $1.0 \mathrm{~m}$ has allowed to detect fine lateral and vertical changes in the cover. The 
use of two measurements sequences along the same profile has allowed us to notice differences in the resulting model resistivity. The presence of three different layers (between 5 and $25 \mathrm{~m}$ of the origin of the $\mathrm{AB}$ profile) on the model resistivity with $\mathrm{a}=0.5$ $\mathrm{m}$ has been observed whereas they are only two on the model resistivity with $\mathrm{a}=1.0 \mathrm{~m}$ for which the third layer between 1.1 and $1.8 \mathrm{~m}$ deep has not been identified. As the cover composition displays on the $0.5 \mathrm{~m}$ model resistivity is in agreement with the materials met at the manual auger holes, we realize that the inversion taking account very low resistivities (waste) provides a biased model resistivity. That's why it appears necessary to inverse data without the bottom conductive levels $(\rho<10 \Omega . m)$ corresponding to the waste in order to have a more realistic image of the cover.

The ERT has also put in evidence the existence of high electrical resistivity variations at the GCL's depth (-1.1 m deep). Low electrical resistivities $(\rho<140 \Omega . m)$ displayed on the model resistivity correspond to a GCL characterized by a value of $12000 \Omega . \mathrm{m}$ thanks to forward modeling. It means that in this case the GCL is damaged and/or saturated because electrical resistivities reach about $4000 \Omega . \mathrm{m}$ on the model resistivity in the case of an undamaged and less saturated GCL defined by a value of at least $120000 \Omega . m$ for a $7 \mathrm{~mm}$ thickness.

The variability of the damaging condition of the GCL has an influence on the estimation of the waste depth on the model resistivity. Thus, when the GCL is the most resistive, the waste depth on the model resistivity is overestimated in comparison to the reality. On the contrary, when the GCL is damaged, the waste depth estimated on the $0.5 \mathrm{~m}$ model resistivity is close to the depth found with manual auger holes. In this case, a small difference (less than $10 \%$ ) has been noticed between the estimated and real depths. 
SP measurements have revealed a sharp negative anomaly observed at the top of the landfill that seems to be linked with the presence of waste shallower that somewhere else.

Based on these results, the area located at the top of the landfill characterized by a cover with a damaged and/or saturated GCL and the presence of waste near to the surface could be considered as a preferential water infiltration zone. Numerous defects have also been noticed along the ERT profile, linked more particularly with low resistivity at the GCL's depth.

This study has shown the contribution brought by the geophysical methods to improve the knowledge of the cover. Use these non-destructive tools associated with manual auger holes can help the site managers to optimize a suited remediation of the cover (total rebuilding or just on a specific area).

\section{References}

Abu-Hassanein Z.S., Benson C.H. and Blotz L.R. 1996. Electrical resistivity of compacted clays. Journal of Geotechnical Engineering 122, 397-406.

Arora T., Linde L., Revil A. and Castermant J. 2007. Non-intrusive characterization of the redox potential of landfill leachate plumes from self-potential data. Journal of Contaminant Hydology 92, 274-292.

ASTM D6747. Standard Guide for Selection of Techniques for Electrical Detection of Potential Leak Paths in Geomembranes. 
Beck A. 2011. Technical improvements in Dipole Geoelectric Survey Methods. Symposium on geosynthetics (GEOFRONTIERS), Dallas, USA. doi: $10.1061 / 41165(397) 290$.

Bernstone C., Dahlin T., Ohlsson T. and Hogland W. 2000. DC-resistivity mapping of internal landfill structures: two pre-excavation surveys. Environmental Geology 39, 360-371.

Besson A., Cousin I., Samouëlian A., Boizard H. and Richard G. 2004. Structural heterogeneity of the soil tilled layer as characterized by 2D electrical resistivity surveying. Soil and Tillage Research, 239-249.

Bolève A., Revil A., Janod F., Mattiuzzo J.L. and Fry J.-J. 2009. Preferential fluid flow pathways in embankment dams imaged by self-potential tomography. Near Surface Geophysics, 447-462.

Boudreault J.P., Dube J.S., Chouteau M., Winiarski T. and Hardy, E. 2010. Geophysical characterization of contaminated urban fills. Engineering Geology 116, 196-206.

Brunet P., Clément R. and Bouvier C. 2010. Monitoring soil water content and deficit using Electrical Resistivity Tomography (ERT) - A case study in the Cevennes area, France. Journal of Hydrology 380, 146-153.

Campana S. and Dabas D. 2011. Archeological Impact Assessment : The BREBEMI Project (Italy). Archeological Prospection 18, 139-148.

Carpenter P.J., Calkin S.F. and Kaufmann R.S. 1991. Assessing a fractured landfill cover using electrical resisitivty and seismic refraction techniques. Geophysics 56, $1896-1904$. 
Cassiani G., Fusi N., Susanni D. and Deiana R. 2008. Vertical radar profiling for the assessment of landfill capping effectiveness. Near Surface Geophysics 6, 133142.

Chambers J.E., Kuras O., Meldrum P.I., Ogilvy R.D. and Hollands J. 2002. Electrical resistivity tomography applied to geologic, hydrogeologic, and engineering investigations at a former waste-disposal site. Geophysics 71, 231-239.

Clément R., Oxarango L. and Descloitres M. 2011. Contribution of 3-D time-lapse ERT to the study of leachate recirculation in a landfill. Waste Management 31, 457467.

Colucci P., Darilek G.T., Laine D.L. and Binley A. 1999. Locating landfill leaks covered with waste. Symposium on Waste Management and Landfill, Cagliari, Italy.

Costantini E.A.C., Andrenelli M.C., Bucelli P., Magini S., Natarelli L., Pellegrini S., Perria R., Storchi P. and Vignozzi N. 2009. Strategies of ARP application (Automatic Resistivity Profiling) for viticultural precision farming. Geophysical Research Abstracts 11, EGU2009-8061-1.

Dabas M. 2009. Theory and practice of the new fast electrical imaging system ARPC. In : Seeing the Unseen. Geophysics and Landscape Archaeology (eds S. Campana and S. Piro), 105-126. CRC Press.

Doussan C., Jouniaux L. and Thony J.L. 2002. Variations of self-potential and unsaturated water flow with time in sandy loam and clay loam soils. Journal of Hydrology 267, 173-185.

Edwards L.S. 1977. A modified pseudosection for resistivity and IP. Geophysics 42, 1020- 1036. 
Forget B., Rollin A.L. and Jacquelin T. 2005. Lessons learned from 10 years of leak detection surveys on geomembrane. Symposium on Waste Management and Landfill, Sardinia, Italy.

Gallas J.D.F., Taioli F. and Filho W.M. 2010. Induced polarization, resistivity, and selfpotential : a case history of a contamination evaluation due to landfill leakage. Environmental Earth Sciences 63, 251-261. ISSN : 1866-6280.

Gebbers R., Lück E., Dabas M. and Domsch H. 2009. Comparison of instruments for geoelectrical soil mapping at the field scale. Near Surface Geophysics 7, 179190.

Genelle F., Sirieix C., Naudet V., Dubearnes B., Riss J., Naessens F., Renié S., Trillaud S., Dabas M. and Bégassat P. 2010. Test de méthodes géophysiques sur couvertures de CSD : site expérimental. Journées nationales de géotechnique et de géologie de l'ingénieur. Grenoble, France.

Genelle F., Sirieix C., Naudet V., Riss J., Naessens F., Renié S., Dubearnes B., Bégassat P., Trillaud S. and Dabas M. 2011a. Geophysical methods applied to characterize landfill covers with geocomposite. Symposium on geosynthetics (GEOFRONTIERS), Dallas, USA. doi:10.1061/41165(397)199.

Genelle F., Sirieix C., Riss J., Naessens F., Renié S., Dubearnes B., Bégassat P. and Naudet V. 2011b. Suivi par tomographie de résistivité électrique d'une couverture de centres de stockage de déchets, à l'échelle d'un site expérimental. Congrès sur le thème de la géophysique et des milieux poreux (GEOFCANGFHN), Orléans, France. ISSN : 0997-1076. pp 45-48.

Ghinassi G., Pagni P.P and Vieri M. 2010. Optimizing vineyard irrigation through the automatic resistivity profiling (ARP) technology. The proposal of a 
methodological approach. $10^{\text {th }}$ International Conference on Precision Agriculture, Denver, USA.

Grellier S., Guérin R., Robain H., Bobachev A., Vermeersch F. and Tabbagh A. 2008. Monitoring of leachate recirculation in a bioreactor landfill by $2 \mathrm{D}$ electrical resistivity imaging. Journal of Environmental and Engineering Geophysics 13, 351-359.

Guérin R., Bégassat P., Benderitter Y., David J., Tabbagh A., and Thiry M. 2004. Geophysical study of the industrial waste land in Mortagne-du-Nord (France) using electrical resistivity. Near Surface Geophysics 3, 137-143.

Guyonnet D., Gourry J.-C., Bertrand L. and Amraoui N. 2003. Heterogeneity detection in an experimental clay liner. Can. Geotech 40, 149-160.

Hansen R. and Beck A. 2009. Electrical Leak Location Surveys for Landfill Caps. Symposium on the perspective on environmental and water resources (Environmental and Water Resources Institute conference), Bangkok, Thailand.

Johansson S. and Dahlin T. 1996. Seepage monitoring in an earth embankment dam by repeated resistivity measurements. European Journal of Environmental and Engineering Geophysics 1, 229-247.

Journal Officiel de la République Française (30 mars 1993). Arrêté du 18 décembre 1992 relatif au stockage de certains déchets industriels spéciaux ultimes et stabilisés pour les installations existantes.

Jouniaux L., Maineult A., Naudet V., Pessel M. and Sailhac, P. 2009. Review of selfpotential methods in hydrogeophysics. Comptes Rendus Geosciences 341, 928936. 
Laine D.L., Binley A.M. and Darilek G.T. 1997. Locating Geomembrane Liner Leaks Under Waste in a Landfill. Symposium on geosynthetics, Long Beach California, USA.

Leroux V., Dahlin T. and Svensson M. 2007. Dense resistivity and induced polarization profiling for a landfill restoration project at Härlöv, Southern Sweden. Waste Management and Research 25, 49-60.

Linde N., Doetsch J., Jougnot D., Genoni O., Dürst Y., Minsley B. J., Vogt T., Pasquale N. and Luster J. 2011. Self-potential investigations of a gravel bar in a restored river corridor. Hydrology and Earth System Sciences 15, 729-742.

Loke M.H., Acworth I. and Dahlin T. 2003. A comparison of smooth and blocky inversion methods in 2D electrical imaging surveys. Exploration Geophysics 34, 182-187.

Loke M.H. 2010. Tutorial : 2-D and 3-D electrical imaging surveys.

Maineult A., Bernabé Y. and Ackerer P. 2004. Electrical response of flow, diffusion and advection in a laboratory sand-box, Vadose Zone Journal 3, 1180-1192.

Maineult A., Strobach E. and Renner J. 2008. Self-potential signals induced by periodic pumping tests, Journal of Geophysical Research 113.

Michot D., Benderitter Y., Dorigny A., Nicoullaud B., King D. and Tabbagh A. 2003. Spatial and temporal monitoring of soil water content with an irrigated corn crop cover using surface electrical resistivity tomography. Water Resources Research 39, 1138.

Naudet V., Revil A., Rizzo E., Bottero J.-Y. and Bégassat P. 2004. Groundwater redox conditions and conductivity in a contaminant plume from geoelectrical investigations. Hydrology and Earth System Sciences 8, 8 - 22. 
Naudet V.and Revil A. 2005. A sandbox experiment to investigate bacteria-mediated redox processes on self-potential signals, Geophysical Research Letters 32, L11405.

Ogilvy R.D., Meldrum P.I.., Chambers J.E. and Williams G. 2002. The use of 3D electrical resistivity tomography to characterise waste and leachate distributions within a closed landfill, Thriplow, UK. Journal of Environmental and Engineering Geophysics 7, 11-18.

Papadopoulos N.G., Tsokas G.N., Dabas M.,Yi M-J., Kim J-H. and Tsourlos P. 2009. Three-dimensional inversion of Automatic Resistivity Profiling data. Archeological Prospection 16, 267-278.

Petiau, G. 2000. Second generation of lead-lead chloride electrodes for geophysical applications. Pure and Applied Geophysics 157, 357-382.

Reynolds J.M. and Taylor D.I. 1996. Use of geophysical surveys during the planning, construction and remediation of landfills. Engineering Geology Special Publications 11, 93-98

Rizzo E., Suski B., Revil A., Straface S. and S. Troisi. 2004. Self-potential signals associated with pumping tests experiments. Journal of Geophysical Research. doi:10.1029/2004JB003049.

Samouëlian A., Cousin I., Richard G., Tabbagh A. and Bruand A. 2003. Electrical Resistivity Imaging for Detecting Soil Cracking at the Centimetric Scale. Soil Science Society of America 67, 1319-1326.

Schwartz B.F., Schreiber M.E. and Yan T. 2008. Quantifying field-scale soil moisture using electrical resistivity imaging. Journal of Hydrology 362, 234-246. 
Sjödahl P., Dahin T., Johansson S. and Loke M.H. 2008. Resistivity monitoring for leakage and internal erosion detection at Hällby embankment dam. Journal of Applied Geophysics 65, 155-164.

Thony J.L., Morat P., Vachaud G.and Le Mouël J.L., 1997. Field characterization of the relationship between electrical potential gradients and soil water flux. CR Acad. Sci. Paris, Earth Planetary Sci. 325, 317-321.

Tye A.M., Kessler H., Ambrose K., Williams J.D.O., Tragheim D., Scheib A., Raines M. and Kuras O. 2011. Using integrated near-surface geophysical surveys to aid mapping and interpretation of geology in an alluvial landscape within a 3D soilgeology framework. Near Surface Geophysics 9, 15-31.

Vaudelet P., Schmutz M., Pessel M., Franceschi M., Guérin R., Atteia O., Blondel A., Ngomseu C., Galaup S., Rejiba F. and Bégassat P. 2011. Mapping of contaminant plumes with geoelectrical methods. A case study in urban context. Journal of Applied Geophysics. doi: 10.1016/j.jappgeo.2011.09.023

White C.C. and Barker R.D. 1997. Electrical leak detection system for landfill liners: a case history. GWMR, 153-159 